\title{
Influence of Low Oxygen Levels in Aeroponics Chambers on Eucalypt Roots Infected with Phytophthora cinnamomi
}

\author{
Treena Burgess, Jen McComb, and Giles Hardy, Biological Sciences, Murdoch University, Perth, Western Aus- \\ tralia, 6150, and Ian Colquhoun, Alcoa of Australia Limited, Perth, Western Australia, 6153
}

\begin{abstract}
Burgess, T., McComb, J., Hardy, G., and Colquhoun, I. 1998. Influence of low oxygen levels in aeroponics chambers on eucalypt roots infected with Phytophthora cinnamomi. Plant Dis. 82:368-373.

Aeroponics root chambers were designed to evaluate the influence of low oxygen on disease development in clones of Eucalyptus marginata susceptible or resistant to infection by Phytophthora cinnamomi. Actively growing 7-month-old clones of E. marginata were transferred into the aeroponics chambers, into which a nutrient solution was delivered in a fine spray, providing optimal conditions for root growth. Prior to inoculation by zoospores of $P$. cinnamomi under normal oxygen, the roots were exposed to four treatments: (i) normal oxygen, approxi-

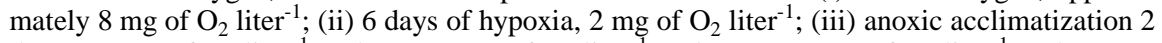
days at $2 \mathrm{mg}$ of $\mathrm{O}_{2} \operatorname{liter}^{-1}, 2$ days at $1 \mathrm{mg}^{-} \mathrm{O}_{2} \operatorname{liter}^{-1}, 2$ days at $0.5 \mathrm{mg}$ of $\mathrm{O}_{2} \operatorname{liter}^{-1}, 2$ days at 2

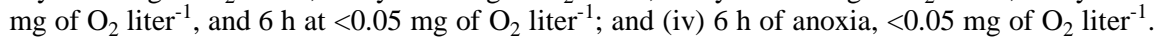
Root extension during hypoxia was greatly reduced. Lesion development was least for roots exposed to hypoxia and greatest for roots exposed to anoxia for $6 \mathrm{~h}$, suggesting increased resistance of E. marginata to P. cinnamomi following hypoxia.
\end{abstract}

Phytophthora cinnamomi is a major pathogen of Eucalyptus marginata (jarrah) in Western Australia (23). It can kill trees of all ages through infection of roots $(10,27)$ or by girdling the trunks of 1 - to 7 year-old trees in situations were the collar is ponded $(12,19)$. Field observations have indicated that periods of waterlogging (low oxygen) can result in the rapid death of trees from $P$. cinnamomi infection $(7,12)$. Flooded soils are assumed to increase disease severity by increasing the mobility of zoospores and by adversely affecting host physiology, resulting in predisposition or poor regeneration of damaged roots $(18,29)$. Jarrah roots exposed to waterlogging produced tyloses that blocked the xylem vessels of the roots and prevented water movement (8). Glasshouse studies with 3- to 4-month-old jarrah seedlings have shown that waterlogging, simultaneously with inoculation or after inoculation with zoospores of $P$. cinnamomi, increased the number, but not the size, of lesions compared with nonwaterlogged seedlings (9). However, seedlings waterlogged before inoculation had very few lesions compared with those waterlogged infected

Corresponding author: Treena Burgess

E-mail: burgess@central.murdoch.edu.au

Accepted for publication 13 November 1997.

Publication no. D-1998-0205-01R

(C) 1998 The American Phytopathological Society simultaneously with or after inoculation (9). This observation is contrary to observations of predisposition to Phytophthora root rots following waterlogging in rhododendrons (4), walnuts (18), cherries (28), alfalfa (17), and safflower (13).

Soil-based studies do not allow the precise control of soil oxygen levels or observation of the effect of low oxygen on root development and subsequent infection development. As the impediment of gaseous exchange caused by static water around roots and the subsequent decrease in oxygen levels is the main cause of root damage in waterlogged soils (16), hydroponic and aeroponics systems can be adapted to study the effect of low oxygen on root development. Hydroponic systems are commonly used in the investigation of physiological and biochemical changes in roots and shoots under anoxic and hypoxic conditions $(1,3,11)$. However, jarrah does not produce roots as rapidly as do crop species, and hydroponic systems do not allow for spot inoculation of roots with zoospores. In contrast, aeroponics systems are simple to maintain for long periods and allow for the nondestructive or sequentially destructive observations during disease development $(20,21,26,30)$. In an aeroponics system, the effect of low oxygen on root development can be separated from the effect of chemical and biochemical reductions and changes to microbial metabolism that also occur in the soil under waterlogged conditions (16).
The aim of this study was to develop a system to allow the investigation of root and lesion development in E. marginata infected with $P$. cinnamomi under precisely controlled oxygen conditions.

\section{MATERIALS AND METHODS}

Aeroponics chambers. The aeroponics chambers were based on those of Wagner and Wilkinson (26) with a number of modifications. Briefly, the chambers were cubes with $60-\mathrm{cm}$ sides fitted with removable lids in three panels, each with 12 holes ( $5 \mathrm{~cm}$ diameter) to hold the plants (Figs. 1 and 2A). The holes were spaced at 9-cm intervals, and the base of the lids was lined with sponge to reduce air exchange between the boxes and the external environment. Each lid was a free-standing unit with legs $(10 \mathrm{~cm})$. At the base of the legs, a 1-cm nylon mesh supported the plant root balls and separated the roots as they grew into the chamber. The chambers were constructed from gray polyvinyl chloride (PVC, $8 \mathrm{~mm}$ thickness). Two portholes (20 $\mathrm{cm}$ diameter) of clear PVC held in place by clamps were placed in the front and back to allow observation of and easy access to the roots (Fig. 1). The portholes were covered with sliding panels to prevent light from affecting root growth. To reduce temperature fluctuations, the boxes were insulated with $3 \mathrm{~cm}$ of polystyrene foam covered with reflective foil.

Nutrients $(0.1 \%$ Maxicrop, Multicrop, Davidson, Australia) were delivered by a noncirculating watering system $(8 \mathrm{~s}$ every $20 \mathrm{~min}$ ) through six high-pressure misting nozzles (DAN Irrigation, Israel) evenly spaced and mounted $30 \mathrm{~cm}$ above the bottom of the chamber (Fig. 1). The nozzles were connected to $15-\mathrm{mm}$ PVC pipes, and the misting system was controlled by 15 mm solenoid valves (HR Products, Perth Australia) operated by an electronic timer (JM Irritol, Hardie Irrigation, Laguna Niguel, USA). The spray regime ensured that the roots remained moist throughout the experiment. Nutrients were proportioned by a GEWA fertilizer injector (Georg Wagner, Augsburg, Germany) and pressurized with mains water.

The chambers were almost airtight, and oxygen levels could be manipulated through gas ports located at the base of the boxes (Figs. 1 and 2A). Gas was evenly 
distributed throughout the chamber interior using flexible aquarium stones $(70 \mathrm{~cm}$ long). The gas ports were attached to flexible 5-mm piping (Swagelock Co., Solon, $\mathrm{OH})$, which was in turn linked to gas flow meters (maximum flow rate of 4.3 liters of $\mathrm{N}_{2} \min ^{-1}$ at $25^{\circ} \mathrm{C}$ ) (Fischer Porter, Warminster, USA) and subsequently to nitrogen cylinders through a regulator. The aeroponics chambers were housed in a controlled temperature glasshouse (20 to $27^{\circ} \mathrm{C}$ ). Temperatures within the chambers were also 20 to $27^{\circ} \mathrm{C}$.

Plant material. Micropropagated clonal lines of E. marginata, previously ranked according to their resistance to $P$. cinnamomi $(6,25)$, were supplied by Alcoa of Australia Limited (Perth, Australia). Clonal lines 1JN30, 28B63, and 326J51 were ranked as resistant and line $11 \mathrm{JN} 402$ as susceptible. Clones, 5 months out of tissue culture and with six to eight leaves, were transplanted from small pots $(5 \mathrm{~cm}$ diameter, $15 \mathrm{~cm}$ long) into peat-perlite (2:1, vol/vol) potting mix containing basal nutrients $\left(0.9 \mathrm{~g}\right.$ of IBDU, $0.5 \mathrm{~g}$ of $\mathrm{KNO}_{3}$, $0.5 \mathrm{~g}$ of aerophos, $0.7 \mathrm{~g}$ of $\mathrm{FeSO}_{4}, 1.2 \mathrm{~g}$ of $\mathrm{FeO}, 0.8 \mathrm{~g}$ of dolomite, $0.7 \mathrm{~g}$ of gypsum, and $0.1 \mathrm{~g}$ of trace elements per liter [Richgro]) in drained polystyrene boxes. When transplanting, the bottom and all but $4 \mathrm{~cm}$ of the sides of the plastic pots and the root ball were cut away so that the basal part of the root ball was exposed to the peat-perlite mix. This maintained the integrity of the root ball and allowed new roots to emerge from the exposed root base. Plants were watered twice daily for $10 \mathrm{~min}$. A low level of nutrients $(5.4 \mathrm{mM}$ $\mathrm{N}, 0.8 \mathrm{mM}$ P, $4.3 \mathrm{mM} \mathrm{K}, 0.4 \mathrm{mM} \mathrm{Mg}, 0.75$ $\mathrm{mM} \mathrm{Ca}, 1.1 \mathrm{mM} \mathrm{S}, 50 \mu \mathrm{M} \mathrm{Fe}$, and $3 \mu \mathrm{M}$ $\mathrm{Mn})$ was applied twice weekly to the foli- age and the soil. After 4 to 5 weeks, the clones, which by then had 9 to 12 leaves, were transferred to the aeroponics chambers. The stems were wedged between high-density foam in $1-\mathrm{cm}$ slits in rubber bungs and secured into the lids of the chambers (Fig. 2B). The root balls were suspended in the aeroponics chambers, where they rested on the nylon mesh. Maximum root production was obtained after 6 to 7 weeks in the aeroponics chambers, when each plant had between three and six roots (Fig. 2D).

Gas manipulation. The chambers were sealed and the gas levels manipulated by controlling the nitrogen flow through gas flow meters. Oxygen levels within the chambers were measured using a dissolved oxygen meter (OXI325A; WTW, Weilheim, Germany) calibrated on water saturated air (within the chamber, humidity

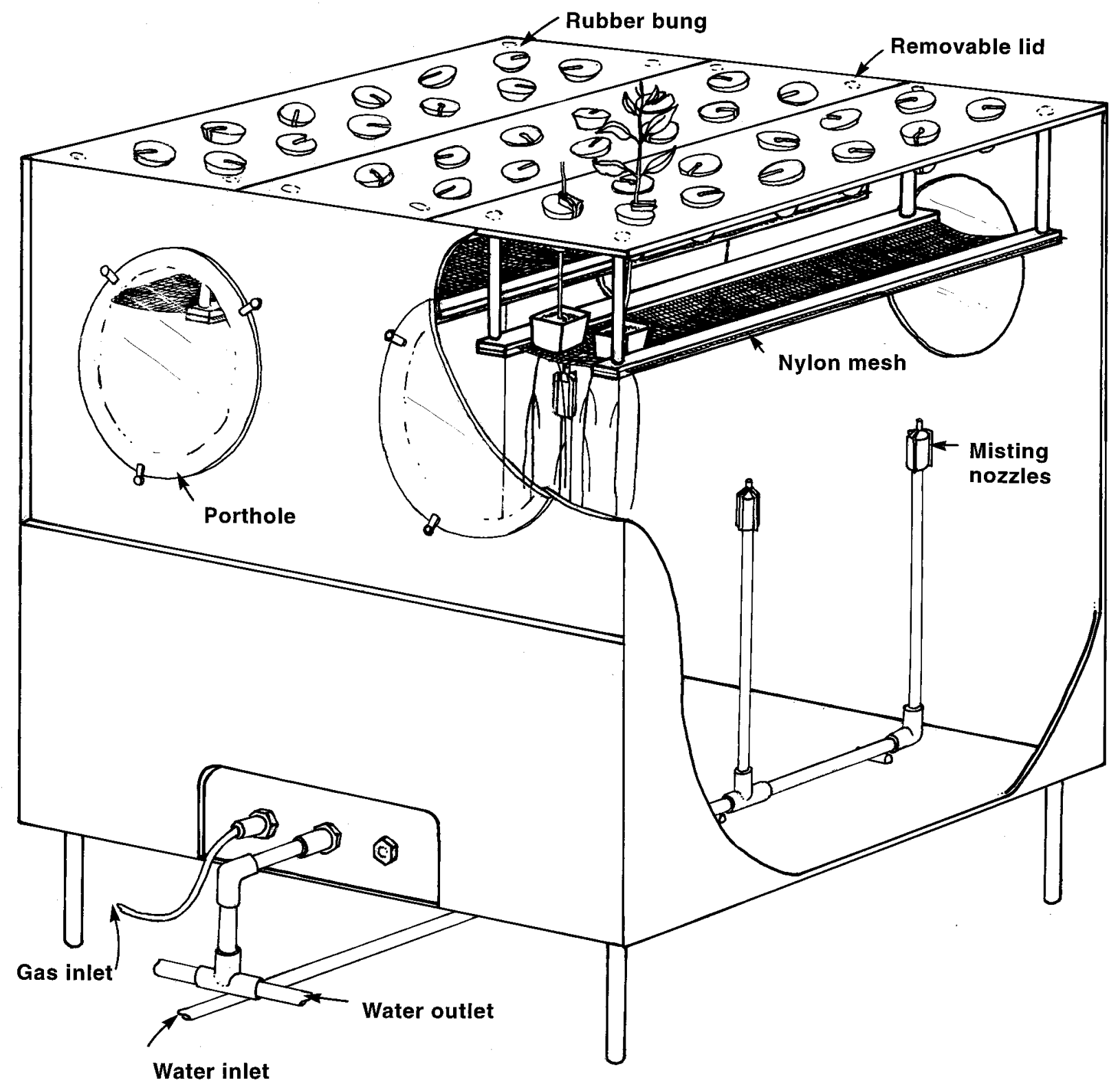

Fig. 1. Diagrammatic representation of the aeroponics chamber indicating the position of high-pressure misting nozzles, removable lids and portholes, nylon mesh that supports the root ball, water and gas inlets, and water outlet. Bar $=10 \mathrm{~cm}$. 
was $100 \%)$. The probes were left in situ for the duration of the experiment. The chambers were first flushed with nitrogen to obtain the desired oxygen concentration. Hypoxic conditions $\left(2 \mathrm{mg}\right.$ of $\mathrm{O}_{2}$ liter $\left.^{-1}\right)$ were maintained by a flow rate of ap- proximately $150 \mathrm{ml}$ of $\mathrm{N}_{2} \mathrm{~min}^{-1}$. Anoxic conditions $\left(0.05 \mathrm{mg} \mathrm{O}_{2}\right.$ liter $\left.^{-1}\right)$ were maintained by a flow rate of 3 liters of $\mathrm{N}_{2} \mathrm{~min}^{-1}$. The gas within the box was mixed by the watering system. The oxygen delivered by the watering system was not sufficient to alter the readings on the dissolved oxygen meter.

Zoospore production. $P$. cinnamomi isolate 94-48, from a diseased jarrah from a rehabilitated mine at Willowdale, Western Australia, had been classified as highly
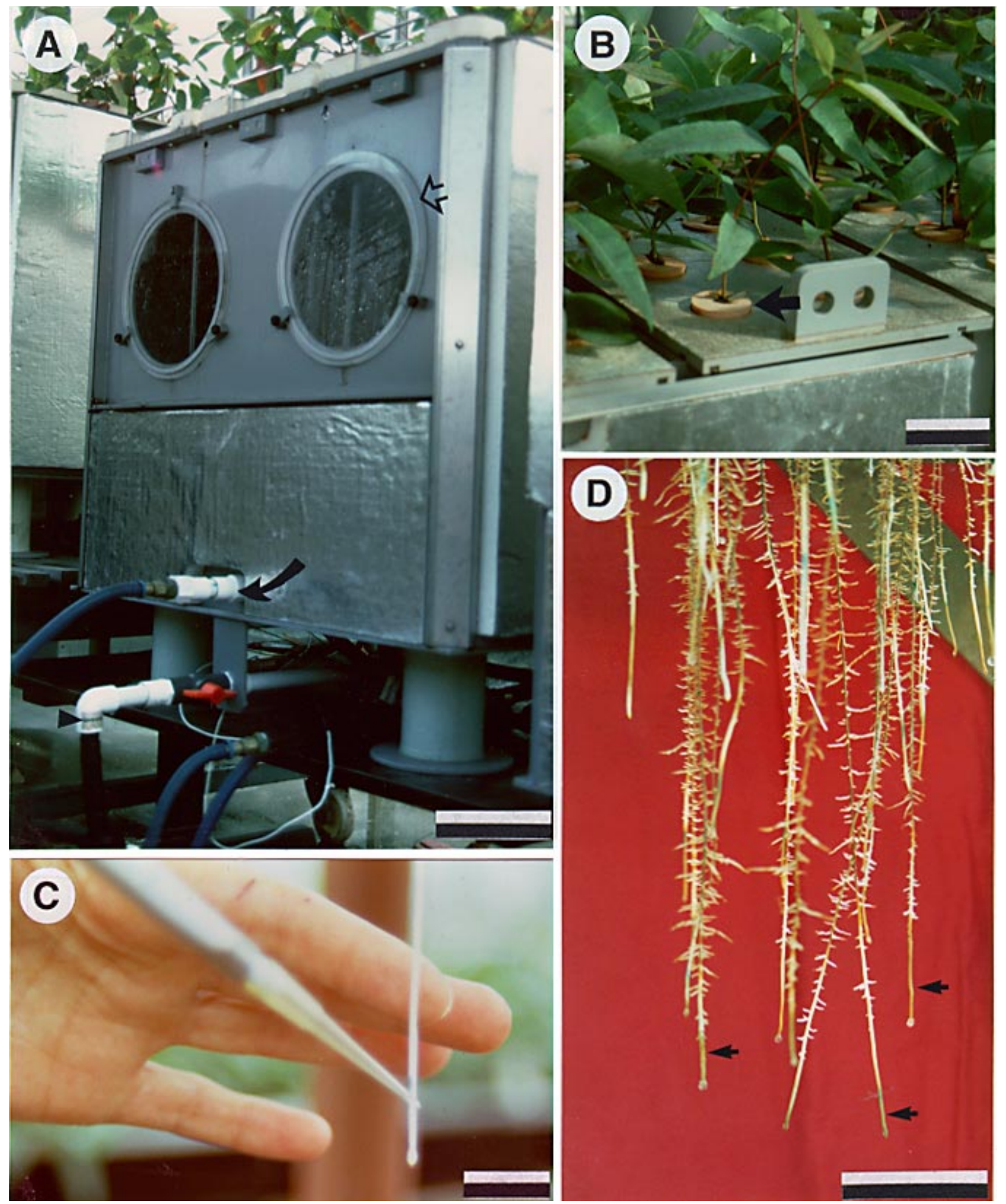

Fig. 2. (A) Aeroponics chamber indicating portholes (open arrow) and water inlet (long arrow) and outlet (short arrow). The gas inlet is obscured by the water inlet. Bar $=10 \mathrm{~cm}$. (B) Rubber bungs (arrow) used to secure the clones into the aeroponics chambers. Bar $=10 \mathrm{~cm}$. (C) Inoculation of root tips with a suspension of Phytophthora cinnamomi zoospores using a Gilson pipette. Bar $=2 \mathrm{~cm}$. (D) Root growth after 6 weeks in an aeroponics chamber. Roots were inoculated with zoospores of $P$. cinnamomi 3 days previously, and lesions (arrows) were 2 to $4 \mathrm{~cm}$ long. Bar $=10 \mathrm{~cm}$. 
pathogenic by Huberli (15). Cultures were maintained routinely on vegetable juice (V8) agar. Zoospores were produced by the method of Byrt and Grant (5) modified by O'Gara et al. (19). Briefly, plugs of fresh mycelia were transferred onto V8 agar overlaid with a sterile cheesecloth square $\left(16 \mathrm{~cm}^{2}\right)$. After 4 days, the cheesecloth was transferred to a 250-ml conical flask containing $150 \mathrm{ml}$ of $\mathrm{V} 8$ broth, shaken overnight at $150 \mathrm{rpm}$ in light, rinsed thoroughly with mineral salts $\left(5 \mathrm{mM} \mathrm{KNO}_{3}, 10 \mathrm{mM}\right.$ $\left.\mathrm{Ca}\left(\mathrm{NO}_{3}\right)_{2} \cdot 4 \mathrm{H}_{2} \mathrm{O}, 4 \mathrm{mM} \mathrm{MgSO}\right)_{4}$, and then shaken overnight in mineral salts to induce the formation of sporangia. The next day, the flasks were placed on a light box for 2 $\mathrm{h}$, cold shocked for $20 \mathrm{~min}$, and then left at room temperature until zoospores were released (usually within 1 to $2 \mathrm{~h}$ ).

Assessment of lesions and root growth. Normal roots are white to approximately 9 $\mathrm{cm}$ behind the root tip, where they turn to brown over a distance of 1 to $2 \mathrm{~cm}$. Brown root indicated the deposit of phenolics and lignin in the cortex, the breakdown of cells in the cortex, and the development of periderm tissue. The rate of root extension was determined by marking the roots with vital stain $(0.1 \%$ methylene blue $) 2 \mathrm{~cm}$ above the root tip prior to the different treatments. After the oxygen treatments, the roots were re-marked $2 \mathrm{~cm}$ above the root tip with another vital stain $(0.1 \%$ neutral red). By comparing the distance between these two marks, the rate of root extension was determined. Lesions were recorded as the discolored apical regions that were brown and water-soaked (Fig. 2D).

Experimental design. There were 12 plants of each clonal line $1 \mathrm{JN} 30$ and $11 \mathrm{JN} 402$ in each of four aeroponics chambers. Prior to inoculation under normal oxygen conditions, roots were exposed to one of four oxygen treatments: (treatment 1) normal oxygen, approximately $8 \mathrm{mg}$ of $\mathrm{O}_{2}$ liter $^{-1}$; (treatment 2) 6 days of hypoxia, $2 \mathrm{mg}$ of $\mathrm{O}_{2}$ liter $^{-1}$; (treatment 3) anoxia acclimation, 2 days of $2 \mathrm{mg}$ of $\mathrm{O}_{2}$ liter $^{-1}, 2$ days of $1 \mathrm{mg}$ of $\mathrm{O}_{2}$ liter $^{-1}, 2$ days of $0.5 \mathrm{mg}$ of $\mathrm{O}_{2}$ liter $^{-1}$, and $6 \mathrm{~h}$ of $<0.05 \mathrm{mg}$ of $\mathrm{O}_{2}$ liter $^{-1}$; and (treatment 4) $6 \mathrm{~h}$ of anoxia, $<0.05 \mathrm{mg}$ of $\mathrm{O}_{2} \operatorname{liter}^{-1}$ (Fig. 3). The duration of hypoxia (6 days) was 2 days longer than that used by Davison and Tay (9) in previous experiments with E. marginata. The short anoxic shock $(6 \mathrm{~h})$ was selected because roots of species such as E. marginata, which are not adapted to waterlogging, are damaged irreversibly by short durations of anoxia (16). Treatments 1 and 2 have been repeated five times for clonal line $1 \mathrm{JN} 30$ and four times for clonal line 11JN402. Only treatments 1 and 2 were applied to clonal lines 28B63 and 326J51. Two hours after the restoration of normal oxygen conditions (day 0 ), the lids containing the plants were removed from the aeroponics chambers, noninoculated roots were removed from four plants of each clone, and the roots tips of four plants from each clone were inoculated with a 5- $\mu$ l drop of zoospore suspension (approximately 15 zoospores) using a Gilson pi-

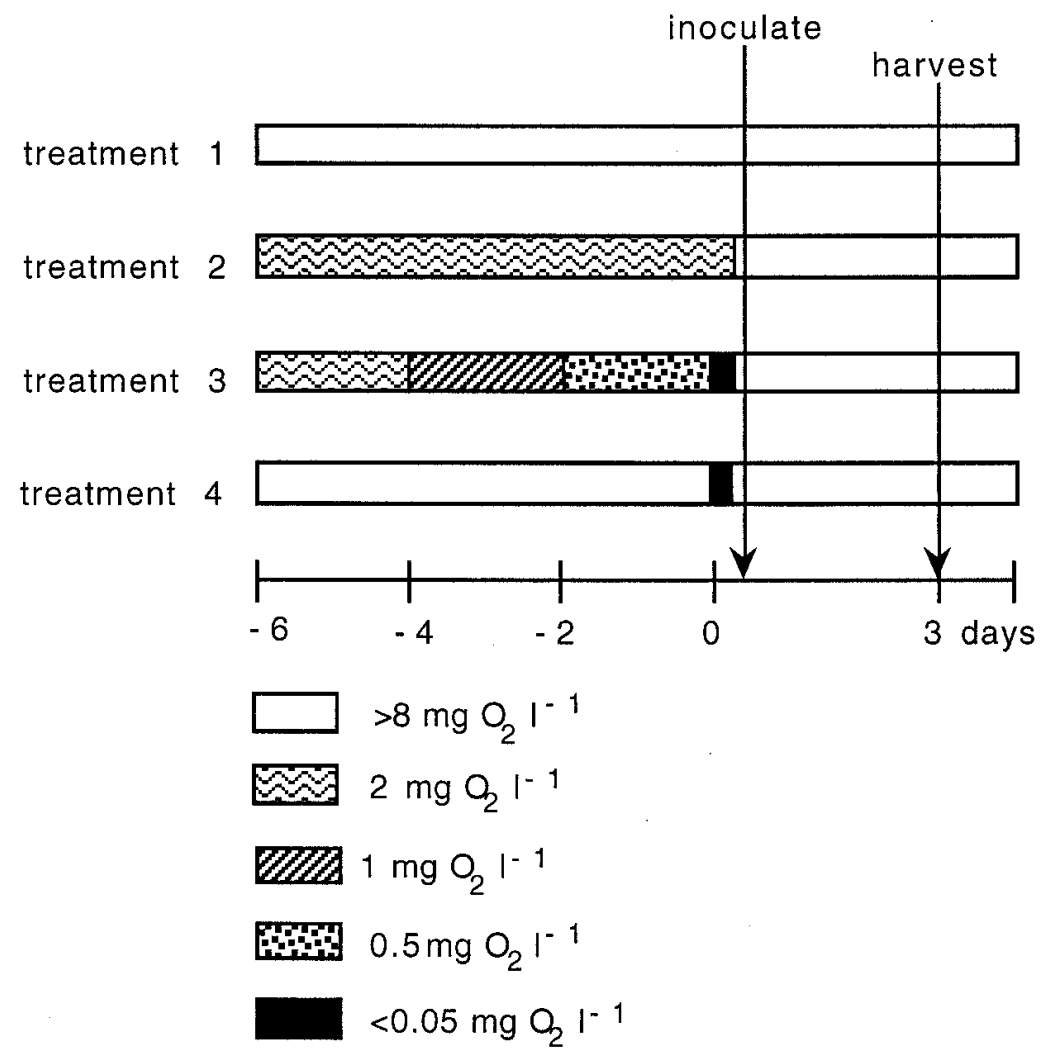

Fig. 3. Bar diagrams indicating the timing of oxygen treatments, inoculation, and harvests. pette (Fig. 2C). After 10 min (to allow for the encystment of zoospores), the lids were replaced in the chambers. Roots were inoculated in the late afternoon and misted constantly to prevent desiccation. Three days later (day 3), the inoculated and noninoculated roots were harvested, and root extension and lesion development were measured. All experiments were analyzed using StatView (TM Abacus Concepts Inc., Berkley, CA, 1992). Means were compared by analysis of variance and presented with standard errors of the mean.

\section{RESULTS}

Effect of low oxygen on root growth and lesion development. Under normal oxygen conditions (treatment 1 ), the rate of lesion development in roots after inoculation with $P$. cinnamomi differed among clones. Lesion extension in the susceptible clone (11JN402) was significantly $(P \leq$ $0.05)$ greater than that for the resistant clones (Fig. 4). Lesion extension posthypoxia (treatment 2$)$ was significantly $(P \leq$ $0.05)$ less than that under normal oxygen for all the clones (Fig. 4), and there were no significant $(P \leq 0.05)$ differences among clones.

The reduction in root growth and lesion development after hypoxia was not significantly different among five separate experiments (Fig. 5). The expense of the clones and the length of each experiment (4 months) did not allow for the repetition of all treatments; however, the low variation among experiments (Fig. 5) strongly suggests that reliable comparisons can be made among treatments in a single experiment.

The resistant clone, $1 \mathrm{JN} 30$, and the susceptible clone, 11J402, responded similarly

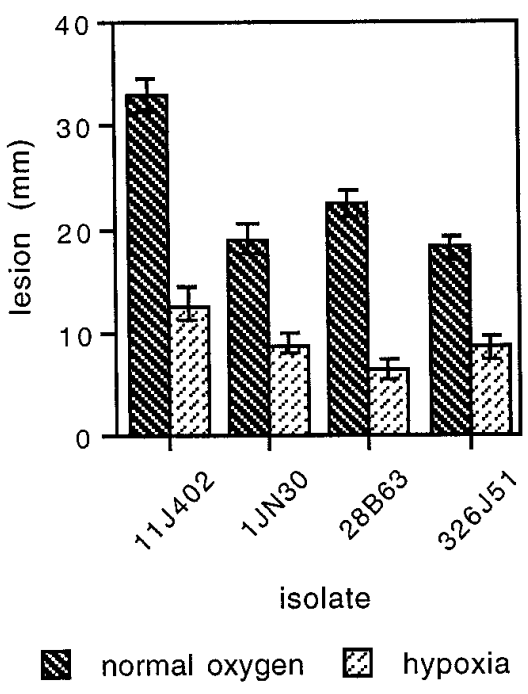

Fig. 4. Development of lesions in different Eucalyptus marginata clones 3 days after inoculating root apices with zoospores of Phytophthora cinnamomi. Clone 11JN402 is classified as susceptible to P. cinnamomi, the others as resistant. 
to the imposed oxygen conditions (Fig. 6). The rate of root extension was reduced during hypoxia (treatments 2 and 3) to less than $50 \%$ of that observed under normal oxygen conditions (treatment 1) (Fig. 6A). Restoration of normal oxygen conditions for 3 days did not increase the rate of root extension in treatments 2 and 3. The rate of root extension during $6 \mathrm{~h}$ of anoxia (treatment 4) was not determined; however, in the 3 days following this anoxic treatment, root extension was dramatically reduced (Fig. 6A).

The length of white root during the hypoxic treatments (treatments 2 and 3) was similar to that under normal oxygen conditions (Fig. 6B). Within 3 days of restoration of normal oxygen levels to hypoxictreated roots, the length of white root had decreased, more so for clone $1 \mathrm{JN} 30$ than for $11 \mathrm{~J} 402$.

Three days after the inoculation of roots, lesions were larger for roots exposed to short-term anoxia (treatment 4) and smaller for those exposed to hypoxia (treatments 2 and 3) when compared with lesions in root grown under normal oxygen condition (treatment 1 ) (Fig. 6C). This difference is also reflected in the percentage of roots in-
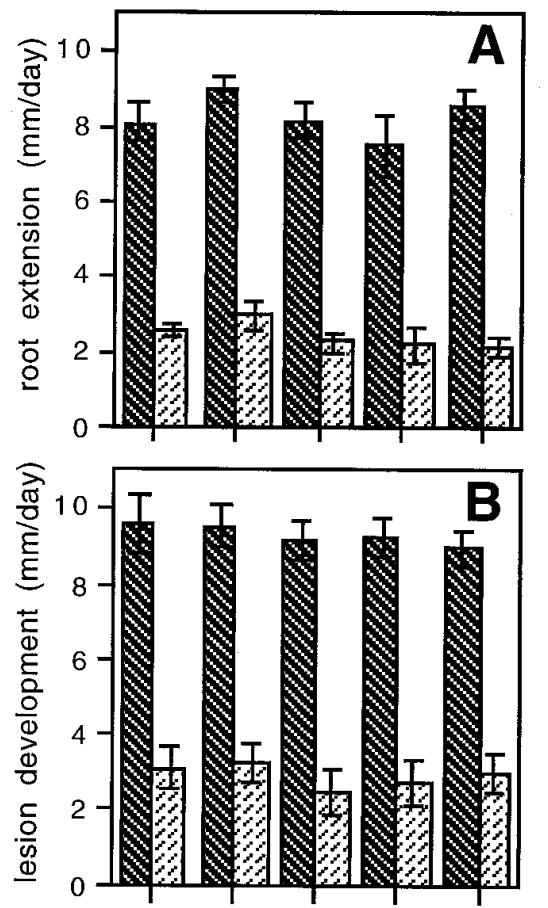

$$
\begin{aligned}
& 1^{9^{90}} 1^{9^{9^{6}}} 1^{9^{9^{6}}} \times 1^{9^{60}} \times 1^{9^{6}}
\end{aligned}
$$

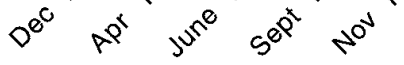

$$
\begin{aligned}
& \text { experiment (date) }
\end{aligned}
$$

$\mathbb{N}$ normal oxygen $\mathbb{Q}$ hypoxia

Fig 5. Reduction in (A) root extension and (B) lesion development in roots of Eucalyptus marginata clone $1 \mathrm{JN} 30$ after a 6-day hypoxic episode. fected. For roots grown under normal oxygen (treatment 1) and roots exposed to short-term anoxia (treatment 4), between 90 and $100 \%$ of roots inoculated developed lesions. In comparison, following hypoxia (treatments 2 and 3), only 50 to $70 \%$ of inoculated roots developed lesions.

There was no difference in the rate of root extension, lesion development, or the length of white root in roots exposed to hypoxia (treatment 2) or those acclimatized to anoxia by pretreatment with hypoxia (treatment 3).

\section{JN30}

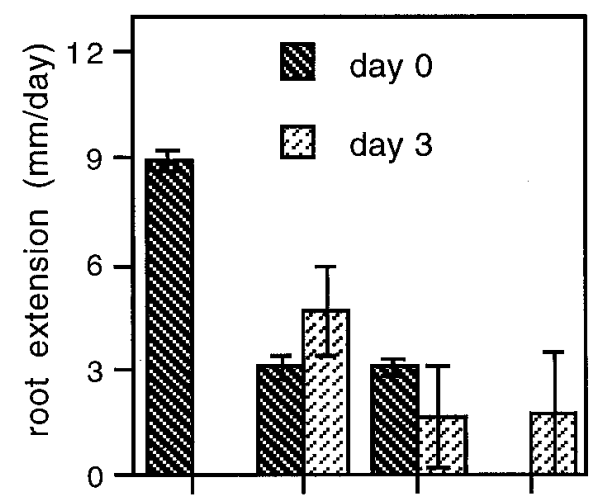

A
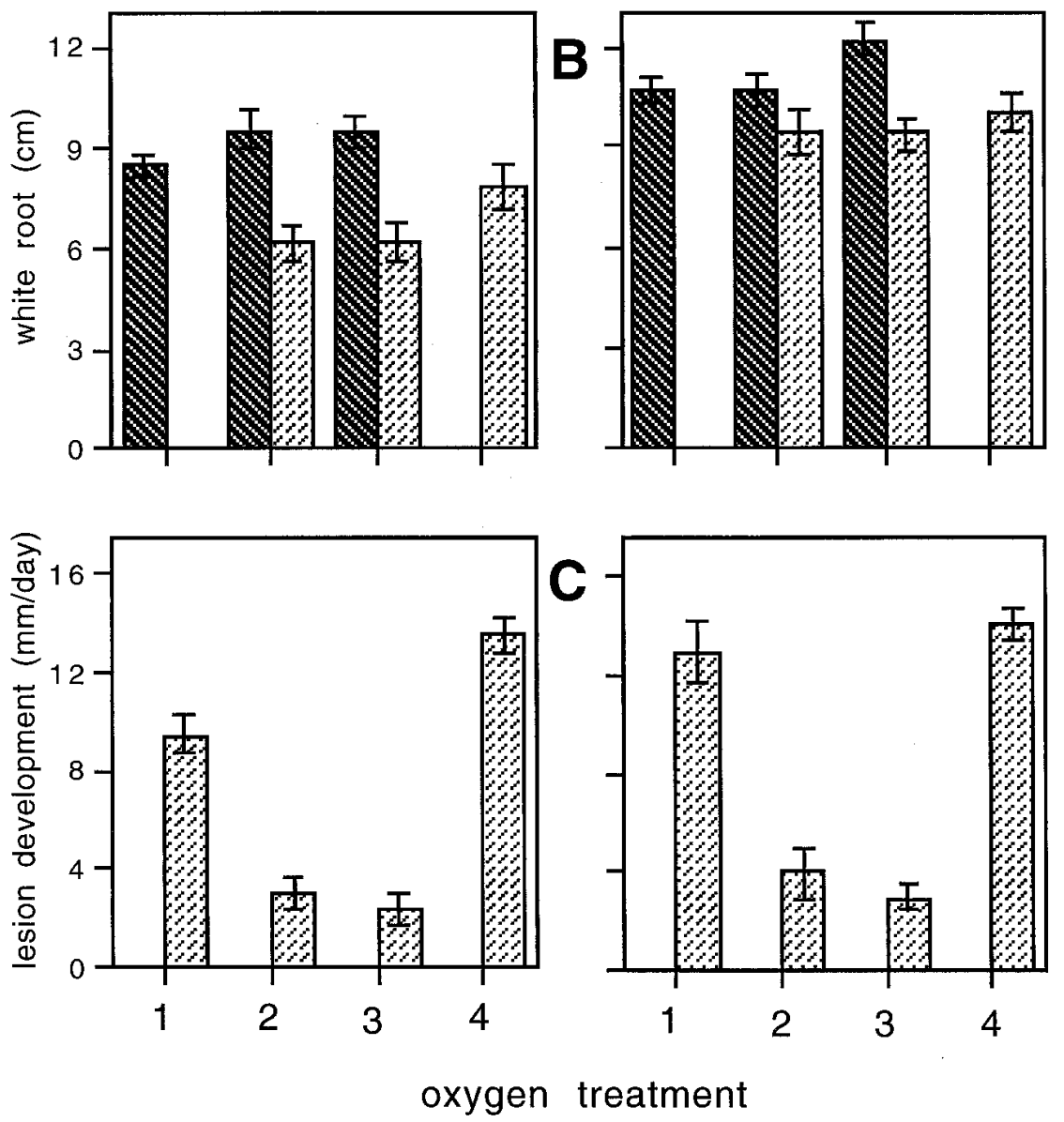

Fig 6. Effect of different oxygen treatments on (A) root extension, (B) length of white root, and (C) lesion development in Eucalyptus marginata clones 1JN30 and 11J402. (See Figure 3 for treatments.)

\section{DISCUSSION}

The aeroponics chambers provided a valuable tool for the study of the effect of oxygen on infection development of the root pathogen P. cinnamomi on E. marginata. These chambers allow for the growth of large numbers of roots that are easily accessible and can be infected without physical damage. In addition, conditions within the chambers are optimal for root growth of E. marginata, as determined by Stoneman (24). Oxygen levels could be regulated easily by altering the flow rate of nitrogen into the chambers. Inoculation of

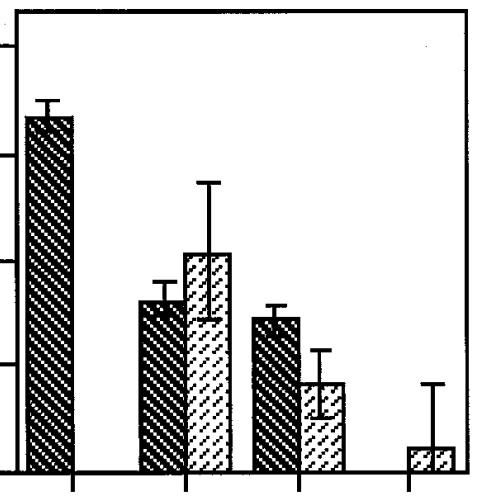

\section{oxygen treatment}


roots with $P$. cinnamomi zoospores was rapid and, unlike in hydroponic systems (3), inoculation could be restricted to the zone of elongation. This is important, as chemotaxis studies have shown that zoospores are preferentially attracted to this region $(14,19)$.

E. marginata clones had been selected based upon their susceptibility to $P$. cinnamomi $(6,25)$. The rate of lesion extension in the aeroponics chambers confirmed these classifications; the lesion extension rate in roots of the susceptible clone was up to twice that of the resistant clones. However, all clones examined responded in a similar way to exposure to hypoxia and anoxia regardless of their susceptibility to $P$. cinnamomi. An anoxic shock (treatment 4) before inoculation always resulted in an increased rate of lesion development compared with that for roots grown under normal oxygen. This was most likely due to tissue damage, as indicated by the reduced rate of root extension of noninoculated roots postanoxia.

The most interesting result was the reduction in lesion development following the 6-day hypoxic episode (treatments 2 and 3 ). This increased resistance to $P$. cinnamomi was observed even for the plants for which hypoxia was followed by a period of anoxia (treatment 3 ). It is a general principle that low oxygen levels predispose roots to infection by root pathogens (22), and in studies with Phytophthora spp., hypoxia has resulted in increased susceptibility $(13,16)$. However, Atwell and Heritage (2) observed reduced susceptibility of safflower to $P$. cryptogea following prolonged hypoxia. They found that while short-term hypoxia (1 day) increased susceptibility, long-term hypoxia (7 days) reduced it. Davison and Tay (9) also observed reduced lesion frequency in 3- to 4month-old jarrah when the roots were inoculated with zoospores of $P$. cinnamomi either postwaterlogging or at day 3 of a 4day waterlogging treatment. The low frequency in the former treatment could be explained by lack of zoospore mobility; however, this does not explain the low frequency in the latter treatment. The increased resistance to infection posthypoxia observed in our study and others $(2,9)$ suggests that there is some induced de novo physiological or biochemical change occurring during hypoxia that results in the increased resistance of roots. Further studies are under way examining the effect of different durations of hypoxia on subsequent infection development.

In conclusion, a simple and reproducible system has been designed for studying the influence of one aspect of the root environment (low oxygen) on disease development in E. marginata infected with $P$. cinnamomi. This system has potential for use with other host-pathogen combinations or to study other factors that affect root growth — such as temperature, nutrient and salt levels, or fungicide and herbicide translocation-while simultaneously altering the gaseous environment.

\section{ACKNOWLEDGMENTS}

We thank Andy Sawyer for making the aeroponics chambers. This project is funded by an Industry Collaborative Grant from the Australian Research Council. Alcoa of Australia Limited supplied the clonal E. marginata as the industry contribution to the grant.

\section{LITERATURE CITED}

1. Andrews, D. L., Drew, M. C., Johnson, J. R., and Cobb, B. G. 1994. The response of maize seedlings of different ages to hypoxic and anoxic stress. Plant Physiol. 105:53-60.

2. Atwell, B. J., and Heritage, A. D. 1994. Reduced susceptibility of roots of safflower to Phytophthora cryptogea after prior adaptation of roots to hypoxic conditions. Aust. J. Bot. 42:29-36.

3. Atwell, B. J., Thomson, C. J., Greenway, H., Ward, G., and Waters, I. 1985. A study of the impaired growth of roots of Zea mays seedlings at low oxygen concentrations. Plant Cell Environ. 8:179-188.

4. Blaker, N. S., and MacDonald, J. D. 1981. Predisposing effects of soil moisture extremes on the susceptibility of rhododendron to Phytophthora root and crown rot. Phytopathology 71:831-834.

5. Byrt, P., and Grant, B. R. 1979. Some conditions governing zoospore production in axenic cultures of Phytophthora cinnamomi Rands. Aust. J. Bot. 27:103-115.

6. Cahill, D. M., Bennett, I. J., and McComb, J. A. 1992. Resistance of micropropagated Eucalyptus marginata to Phytophthora cinnamomi. Plant Dis. 76:630-632

7. Davison, E. M. 1994. Role of the environment in dieback of jarrah: Effects of waterlogging on jarrah and Phytophthora cinnamomi and infection of jarrah by P. cinnamomi. J. Royal Soc. West. Aust. 77:123-126.

8. Davison, E. M., and Tay, F. C. S. 1985. The effect of waterlogging on seedlings of Eucalyptus marginata. New Phytol. 101:743-753.

9. Davison, E. M., and Tay, F. C. S. 1987. The effect of waterlogging on infection of Eucalyptus marginata seedlings by Phytophthora cinnamomi. New Phytol. 105:585-594.

10. Dell, B., and Malajczuk, N. 1989. Jarrah dieback - A disease caused by Phytophthora cinnamomi. Pages 67-87 in: The Jarrah Forest - A Complex Mediterranean Ecosystem. B. Dell, J. Havel, and N. Malajczuk, eds. Kluwer, Dordrecht.

11. Gibbs, J., de Bruxelle, G., Armstrong, W., and Greenway, H. 1995. Evidence for anoxic zones in 2-3 mm tips of aerechymatous maize roots under low oxygen supply. Aust. J. Plant Physiol. 22:723-730.

12. Hardy, G. S. J. E., Colquhoun, I. J., and Nielsen, P. 1996. The early development of disease caused by Phytophthora cinnamomi in Eucalyptus marginata and Eucalyptus calophylla growing in rehabilitated mine sites. Plant Pathol. 45:944-954.

13. Heritage, A. D., and Duniway, J. M. 1985. Influence of depleted oxygen supply on Phytophthora root rot of safflower in nutrient solution. Pages 199-202 in: Ecology and Management of Soilborne Plant Pathogens. C.
A. Parker, A. D. Rovira, K. J. Moore, and P. T. W. Wong, eds. The American Phytopathological Society, St. Paul, MN.

14. Hinch, J., and Weste, G. 1979. Behaviour of Phytophthora cinnamomi zoospores on roots of Australian forest species. Aust. J. Bot. 27:679-691.

15. Huberli, D. 1995. Analysis of variability among isolates of Phytophthora cinnamomi Rands from Eucalyptus marginata Donn ex $\mathrm{Sm}$ and Eucalyptus calophylla $\mathrm{R}$.Br. based on cultural characteristics, sporangia and gametangial morphology, and pathogenicity. Honours thesis. Murdoch University, Perth, Western Australia.

16. Jackson, M. B., and Drew, M. C. 1984. Effects of flooding on growth and metabolism of herbaceous plants. Pages 47-127 in Flooding and Plant Growth. T. T. Kozlowski, ed. Academic Press, Orlando.

17. Kuan, T.-L., and Erwin, D. C. 1980. Predisposition effect of water saturation of soil on Phytophthora root rot of alfalfa. Phytopathology 70:981-986.

18. Matheron, M. E., and Mircetich, S. M. 1985. Relative resistance of different rootstocks of English walnut to six Phytophthora spp. that cause root and crown rot in orchard trees. Plant Dis. 69:1039-1041.

19. O'Gara, E., Hardy, G. E. S. J., and McComb, J. 1996. The ability of Phytophthora cinnamomi to infect through unwounded and wounded periderm tissue of Eucalyptus marginata. Plant Pathol. 45:955-963.

20. Rao, A., Gritton, E. T., Grau, C. R., and Peterson, L. A. 1995. Aeroponics chambers for evaluating resistance to Aphanomyces root rot of peas (Pisum sativum). Plant Dis. 79:128-132.

21. Schoeneweiss, D. F. 1975. A method for controlling plant water potentials for studies on the influence of water stress on disease susceptibility. Can. J. Bot. 53:647-652.

22. Schoeneweiss, D. F. 1975. Predisposition, stress and plant disease. Annu. Rev. Phytopathol. 13:193-211

23. Shearer, B., and Tippett, J. 1989. Jarrah dieback: The dynamics and management of Phytophthora cinnamomi in the jarrah (Eucalyptus marginata) forest of south-western Australia. CALM Bull. no. 3. CALM, Western Australia.

24. Stoneman, G. 1992. Factors affecting the establishment of jarrah (Eucalyptus marginata) from seed in the Northern Jarrah Forest of Western Australia. Ph.D. diss. Murdoch University, Perth, Western Australia.

25. Stukely, M. J. C., and Crane, C. E. 1994 Genetically based resistance of Eucalyptus marginata to Phytophthora cinnamomi. Phytopathology 73:390-397.

26. Wagner, R. E., and Wilkinson, H. T. 1992. An aeroponics system for investigating disease development on soybean taproots infected with Phytophthora sojae. Plant Dis. 76:610614.

27. Weste, G., and Marks, G. C. 1987. The biology of Phytophthora cinnamomi in Australasian forests. Annu. Rev. Phytopathol. 25:207229.

28. Wilcox, W. F., and Mircetich, S. M. 1985. Effects of flooding duration on the development of Phytophthora root and crown rot of cherry. Phytopathology 75:1451-1455.

29. Zentmyer, G. A. 1980. Phytophthora cinnamomi and the diseases it causes. American Phytopathological Society, St. Paul, MN.

30. Zobel, R. W., Del Tredici, P., and Torrey, J. G. 1976. Method of growing plants aeroponically. Plant Physiol. 57:344-346. 